\title{
PEDAGOGICAL CONTENT KNOWLEDGE OF ACCOUNTING TEACHERS IN SOUTH AFRICA: READINESS OF GRADE 9 FOR ACCOUNTING IN GRADE 10
}

\author{
Motalenyane Alfred Modise and Segalo Letlhonyo \\ Faculty of Education, Central University of Technology, Free State \\ mamodise@cut.ac.za,0827036686
}

\begin{abstract}
EMS in grade 9 includes accounting related assessment standards upon which the grade 9 is a platform to prepare Grade 9 learners for Grade 10. especially Accounting curriculum builds. The main objective of the study was to determine pedagogical content knowledge and preparedness of Economic and Management Sciences teachers in preparing Grade 9 for Grade 10 in South Africa .Participants were a purposive sample five senior phase schools in Free State Province in Lejweleputswa District of South Africa were chosen to participate in the study $(60 \%=60$, male, age $28-43)$ who are teaching Economics and Management Science. The qualitative research was used, and EMS teachers completed semi-structured individual interviews on their sense of pedagogical content in teaching Accounting as an integrated subject in South African schools. Thematic analysis indicated that EMS learners master Economics and Business Studies and perform bad in Accounting but proceed to the next level because of the good pass in two subjects. EMS teachers experienced challenges with the terminology and difficult language used in the EMS textbooks. Moreover, the effective teaching and learning strategy is a challenge to most of EMS teachers in schools. The policy, professional development and support for teachers and learners must be given attention to address the challenges faced by EMS teachers and EMS learners, prepare and lay good foundation for Grade 9 learners for Grade 10
\end{abstract}

Keywords: Accounting, EMS, Teachers, Readiness, Pedagogy

\section{INTRODUCTION}

Economic and management Sciences (EMS) in grade 9 includes accounting related assessment standards upon which the grade 10 Accounting curriculum builds. The grade 10 Accounting curriculum is based on the assumption that learners have mastered the related content in grade 9.The study according to Khanare (2012) who, in her study on the teachers' experiences and practices relating to the teaching of Integrated Science in Form Three in Lesotho, came to the conclusion that teachers rarely teach science as an integrated subject. Teachers focus more on what they know best, that is, based on their training they chose to teach Biology, Chemistry or Physics. For example, if one has been trained as a Biology teacher, s/he concentrates more on Biology content and sacrificing curriculum coverage of chemistry and physics. This is because such teachers training institutions train teachers in a disciplined-based model and not interdisciplinary model. 
Apart from the problems associated with the subject content knowledge and teachers' training in the teaching of accounting as an integrated subject in grade nine in South African schools, available literature also suggest challenges are based on the context in which teachers teach. Teaching accounting especially in rural areas pose a major challenge of keeping up to date with the requirements of EMS, especially the teaching of accounting component. The best way to teach leaners to master accounting is through direct experience and practice and the use of active learning (Ngwenya \& Maistry, 2012). However, lack of resources such as proper accounting stationery and financial calculators means that they cannot provide their learners concrete experiences of accounting concepts and practices used in real world.

According to the DoE (2011) the weighting of Curriculum and Economic and Management Science topics are as follows:

\section{TABLE 1: WEIGHTING OF CURRICULUM AND ECONOMIC AND MANAGEMENT SCIENCE TOPICS}

\begin{tabular}{|l|l|}
\hline Weighting of the Curriculum & Topic \\
\hline The Economic (Weighting of 30\%) & $\begin{array}{l}\text { History of money, Needs and wants, Goods and } \\
\text { services, Inequality and Poverty, The Production } \\
\text { function, Government, The National Budget, standard of } \\
\text { living, Markets, Economic systems, the circular flow, The } \\
\text { Price theory and Trade unions }\end{array}$ \\
\hline The Financial literacy (Weighting 40\%) & $\begin{array}{l}\text { Saving, Budget, Income and expenditure, Accounting } \\
\text { concepts, Accounting concepts and Financial } \\
\text { management and keeping of records }\end{array}$ \\
\hline Entrepreneurship ( Weighting (30\%) & $\begin{array}{l}\text { Entrepreneurial skills and knowledge, Business, Factors } \\
\text { of production, forms of ownership, Sectors of economy, } \\
\text { Levels and function of management, Finctions of a } \\
\text { business and business plan }\end{array}$ \\
\hline
\end{tabular}

(DBE, 2011)

\section{CHALLENGES WITH LANGUAGE USED IN THE ACCOUNTING TEXTBOOKS}

There seems to be disparity between the linguistic level of subject textbooks and the reading proficiency of accounting learners. The readability levels of secondary school textbooks are not always in relation to the reading ability of the learners who are expected to learn from them. Many textbooks designed for South African schools are written in a language way beyond the reading comprehension levels of their proposed class levels (Van der Walt, 2013:96). South African publishers attempt to ensure that textbook authors keep in mind that Accounting learners learn through their second or third language and may have considerably dissimilar background knowledge than first language speakers of English. However, publishers do not always succeed in this endeavor. Textbooks are not always written with accounting learners in mind, with the consequence that prescribed textbooks lack clarifying examples and concept explanations needed by accounting learners (Mathew, 2014).

.It is difficult to check and measure readability of textbooks due to the many factors which are involved. Farral (2012) identifies four factors which affect readability of textbooks, namely: content (including prepositions, organisation, coherence), style (including semantic and syntactic elements), design (including typography, format, and illustrations), and structure (including chapters, headings and navigation). Saja and Akerka (2012) indicate that the best predictors of textual difficulty are two aspects of style, namely syntactic structure (e.g. sentence length) and semantic content (e.g. vocabulary). Sternberg and Sternberg (2017) claim that semantic content will assist Accounting learners to identify, understand, and recall the meaning of words they read in the text if the meaning of such words and concepts are explained as footnotes or extra notes to the text (i.e. prepaid expenses, accrued income). 


\section{METHOD}

The study utilised a phenomenological qualitative inquiry (Ary, Jacobs, Razavieh \& Sorensen, 2009) to gain an in-depth understanding of the Pedagogical Content Knowledge of Accounting teachers in South Africa, methodology used to teach Accounting as an integrated subject. A phenomenological inquiry approach is appropriate as the study aims to explore rural, indigenous community experiences of grieving the loss of their partner in a rural setting of South Africa.

\section{PARTICIPANTS AND SETTING}

The participant Accounting teachers $(n=12)$ were a convenience sample (female $=60 \%$, male $=40$ age range $=28$ to 43 years old) in the Free State Province of South Africa. The participants were mainly black, Sesotho speaking. Most of the participant teachers (98\%) self-identified as well experienced teachers.

\section{DATA COLLECTION AND PROCEDURE}

Participants were recruited at school because each was an appropriate place for the participants. The participants volunteered for the study. The purpose of the research was explained to the participants. The names of the respondents were not identified for ethical reasons. The participants provided informed consent to the study. The purpose of the research was explained to the participants. The participant completed a semi-structured individual interview on their personal beliefs and experience. The teachers completed the interviews at convenient locations for them and the lead researcher. Interviews were concurrently transcribed and translated for analysis.

\section{DATA ANALYSIS}

Data were thematically analysed using open-coding procedures ( King \& Horrocks,2010). These procedures involved systematically organising, categorising, and summarising data, followed by describing them in meaningful themes. Themes were assigned codes to condense the data into categories. For the data reporting, randomly assigned numbers as de-identifiers were used.

\section{FINDINGS AND DISCUSSION}

The thematic analysis resulted in the three themes: (i) Language used in the Accounting textbooks, and (iii) challenges with infective teaching of EMS and (iii) Language skills

\subsection{Theme 1: Language Used in the Accounting textbooks}

All participants asserted that they experience learning challenges because they cannot cope with the difficult language (English) emanating from difficult passages in prescribed textbooks. As a result, they cannot discern key points from chunks of information in complex sentences. The problem experienced by learners emanates from the subject teacher, who fails to minimise or remove the barriers by providing instructional help to the learner. T9: "Concepts used in the textbooks are difficult, difficult to cope with those challenging concepts and difficult to understand the concepts in the sentence and we are not getting any support from the teachers with difficult concepts".

All participants indicated that the language used in many sections of the textbooks is problematic for them. They indicated that when the have to engage with the textbook when completing homework exercises, they struggle to find the essences of the transaction, which hampers their ability to successfully record such a transaction. T4: "The language in the Accounting textbooks use is very difficult for me, I do not understand the terms used in the textbook and even is used by the teacher in the classroom, I cannot perform well, and it is difficult to read in the textbook and do the exercise".

In addition, they stated that they sometimes make use of a dictionary to ensure they grasp all the words used in transactions or concept explanations. Their lack of a clear understanding of what they read in the textbook has a direct effect on their academic performance. T7 indicated: "The level of the English language in the textbook is, difficult, we are forced to use dictionary, difficult for us as learners, also for teachers, confusing me as an Accounting learner".

Many participants claimed that their teachers will read from the textbook and then explain some concepts in the mother tongue. This is seen as beneficial by them, although when they are at home they are left to their own interpretations of the textbook, as some of their parents are not able to assist them at home. Some stated that the language used in Accounting textbooks frustrates them and discourages them to commit to homework and the subject. T12: "Many teachers explain Accounting in Sesotho and English because the 
level of English and terms used in the textbooks is very difficult". Participant \#15, male: "I become frustrated and stacked with accounting transaction, discourage, hate the subject and have negative attitude towards Accounting".

The researcher detected that Accounting textbooks used in South African schools are written in a language not necessarily on the reading comprehension levels of accounting learners. Textbooks are not written for accounting learners as the textbooks used are the same used by mother speakers of English. This has a detrimental effect on the academic performance of learners who are always at a disadvantage with regard to textbooks. This is supported by Matthew (2014:1213) who claims that Accounting textbooks are not written with the Accounting learners in mind, with the result that the textbooks lack clarifying examples and concept explanations so direly needed by accounting learners.

At its highest levels, reading encompasses processing, interpreting, and evaluating written language, symbols, and texts with understanding and fluency. The researcher is of the opinion that Accounting learners are obligated to have a good command of the complex concepts of Accounting. They must be able to interpret and infer information from passages of the textbooks. The interpretation is underpinned by the skills needed to recognize words that form links in the learning activities. The textual problems have to do with the concepts, long sentence or phrases, the readability of the textbook and other complex features unfriendly to the learner/user of the material. It seems that the Accounting learners lack English proficiency to read, conceptualise, interpret, analyse information from the textbooks with understanding and critical minds.

\subsection{Theme 2: Challenges with Infective Teaching of Accounting}

Majority of the Accounting teachers lack skills to mediate and support Accounting teachers in classroom and this affect the performance of Accounting learners. The Accounting teachers lack pedagogical content knowledge to mediate.

T3"We do not have sufficient time to teach three subjects in Grade 9 and therefore learners are not well prepared for Grade 10:

T9"Sometimes you become confused in terms of teaching three subjects and mix the terminology or sometime use the same terminology in all the three subjects"

T12"Sometimes confused where to start. ...either with Accounting, Business Studies or Economics"

The study indicated that the teachers lack patience and tact in creating and maintaining rapport between him/herself and the learners. The study shows that teachers should refrain from being didactic instructors to allow learners the opportunity to take responsibility for their own learning and to be independent thinkers and mediate.. This is only possible if educators become mediators in the classroom and allow learners to engage with content (Selaledi, 2013:2). Teachers are expected to be a master of their subject in order to be able to intervene and present their lesson with confidence. It is important for teachers as mediators of learning to open and/or improve interaction between the learner and the lesson content (Zehra \& Carrison, 2013:155,Modise, 2016).

\subsection{Theme 3: Language skills}

$80 \%$ of the learners struggling reading, writing and speaking skills in the Accounting classroom and this affect their academic performance

“T3: "LEP learners struggle with reading, writing, speaking and listening in the Accounting classroom

T7: It is difficult for Accounting learner to speak in English and they prefer to use their mother tongue instead of English"

T4 "Accounting learners struggle to write "in English language and at the same time struggle with Accounting language or use Accounting concepts"

The study showed that $t$ writing, speaking, listening and reading skills are still a problem to Accounting learners. They are unable to use the language correctly, cannot read with understanding especially when reading the Accounting transactions and the use of mother tongue is needed to address the four language skills. The study indicated that a child who is fluent in her/his mother tongue and knowledge and skills that learners develop in one language are potentially transferable to another language (Zacarian, 2011)

\section{DISCUSSION AND CONCLUSION}

The pedagogical Content knowledge of Accounting teachers in South Africa and the readiness of Grade 9 for 
Accounting in Grade 10 is challenge, especially in the subject Accounting. The study revealed that indicated that Accounting learners experience challenges with the language used because they cannot cope with the difficult language (English) emanating from difficult passages in prescribed textbooks of Accounting. The study also indicated that English is a compulsory language to be used for teaching and learning of Accounting in South African schools. The traditional methods used by teacher in the classroom is a challenge since it is teachers centred and not learners centred and therefore it does involve and attract the attention of the learners The study indicated that EMS teachers needed proper training and background knowledge in the disciplines within the learning area in order to interpret the learning outcomes. The study indicated that expressed the view that at most schools EMS was given to teachers who did not have the necessary background and training and was allocated to teachers simply to fill their timetables. These included problems relating to the content of the learning area, the imbalanced of assessment strategy to EMS learners as well as problems with the training of EMS teachers.

The study recommends that an appropriate and suitable language for accounting learners must be used in South African schools, instead of using a foreign language to Accounting learners. The Accounting teachers must shift from teacher's approach method to learners centred approach method, whereby learners are involved and own the lesson. The teacher's approach will promote creativity and critical thinking and in depended by Accounting learners. The innovative and technological training of teachers in fourth industrial revolution is need currently, since current learners are interested in technology. Therefore use of WhatsApp, YouTube. TikTok, WeChat, Instagram, QZone, Weibo, Twitter, Tumblr, Baidu Tieba and Linked and Accounting teacher must be trained on how to use social media to teach Accounting learners in South African schools. Lastly the continuous professional development and policy engagement is critical to development the curriculum and teachers and lay good foundation for Grade 9 learners for Grade 10

\section{REFERENCE LIST}

ARY, J., JACOBS, C. C., RAZAVIEH, A., \& SORENSEN, C. (2009). Introduction to Research in Education. Wadsworth: Engaged Publishing.

DEPARTMENT OF BASIC EDUCATION 2011. Curriculum and Assessment Policy Statemen. Grades 7-9: Economic and Management Sciences. Pretoria: Government Printers

FARRAL, M. 2012. Reading Assessment: Linking Language, Literacy, and Cognition, Canada. John Willey \& Sons.

KHANARE TB 2012. Experiences and Practices of Form Three Integrated Science Teachers with Regard to Outcomes and Assessment Strategies. MEd Thesis. KwaZulu-Natal: University of KwaZulu-Nata

KING,N \& HORROCKS,C. 2010. Interviews in Qualitative Research (pp.142-168).Los Angeles. SAGE

MATHEW, R.M .2014. International Handbook of Research in History, Philosophy and Science Teaching. Sydney: Springer

MODISE,M.A.2016. Pedagogical Content Knowledge Challenges of Accounting Teachers. Int J Edu Sci, 13(3): 291-297 (2016)

NGWENYA, J.C., \& MAISTRY, S. M. 2012. Teaching and assessment in accounting: an exploration of teachers' experiences in a rural KwaZulu-Natal school. Journal of Social Sciences, 33(1): 21-30.

SAJA, P.S., \& AKERKAR, R. 2012. Intelligent Technologies for Web Applications. Boca Raton: Taylor \& Francis Group

STERNBERG, R.J., \& STERNBERG, K. 2017. Cognitive Psychology. Boston: Cengage.

ZACARIAN, D. 2011. Transforming Schools for English Learners: A Comprehensive Framework for School Leaders. London: Corwin 